\title{
Gut microbiota alterations in patients with persistent respiratory dysfunction three months after severe COVID-19
}

Beate Vestad ${ }^{1,2}$, Thor Ueland ${ }^{1,3}$, Tøri Vigeland Lerum ${ }^{3,4}$, Tuva Børresdatter Dahl ${ }^{1,5}$, Kristian Holm ${ }^{1,2,3}$, Andreas Barratt-Due ${ }^{5,6}$, Trine Kåsine ${ }^{3,5}$, Anne Ma Dyrhol-Riise ${ }^{3,7}$, Birgitte Stiksrud ${ }^{3,7}$, Kristian Tonby ${ }^{3,7}$, Hedda Hoel ${ }^{1,3,8}$, Inge Christoffer Olsen ${ }^{9}$, Katerina Nezvalova Henriksen ${ }^{10,11}$, Anders Tveita ${ }^{12}$, Ravinea Manotheepan ${ }^{13}$, Mette Haugli ${ }^{14}$, Ragnhild Eiken ${ }^{15}$, Åse Berg ${ }^{16}$, Bente Halvorsen ${ }^{1,3}$, Tove Lekva ${ }^{1}$, Trine Ranheim $^{1}$, Annika Elisabeth Michelsen ${ }^{1,3}$, Anders Benjamin Kildal ${ }^{17}$, Asgeir Johannessen ${ }^{3,18}$, Lars Thoresen $^{19}$, Hilde Skudal ${ }^{20}$, Bård Reiakvam Kittang ${ }^{21}$, Roy Bjørkholt Olsen ${ }^{22}$, Carl Magnus Ystrøm ${ }^{23}$, Nina Vibeche Skei ${ }^{24}$, Raisa Hannula ${ }^{25}$, Saad Aballi ${ }^{26}$, Reidar Kvåle ${ }^{27}$, Ole Henning Skjønsberg ${ }^{3,4}$, Pål Aukrust ${ }^{1,3,29}$, Johannes Roksund Hov $^{1,2,3,28}$ and Marius Trøseid ${ }^{1,3,29}$ on behalf of the NOR-Solidarity study group

${ }^{1}$ Research Institute of Internal Medicine, Oslo University Hospital, 0424 Oslo, Norway

${ }^{2}$ Norwegian PSC Research Center, Department of Transplantation Medicine, Oslo University Hospital, Oslo, Norway

${ }^{3}$ Institute of Clinical Medicine, University of Oslo, 0315 Oslo, Norway

${ }_{4}^{4}$ Department of Pulmonary Medicine, Oslo University Hospital Ullevål, 0424 Oslo, Norway

${ }^{5}$ Division of Critical Care and Emergencies, Oslo University Hospital, 0424 Oslo, Norway

${ }^{6}$ Division of laboratory Medicine, Dept. of Immunology, Oslo University Hospital, 0424 Oslo, Norway

${ }^{7}$ Department of Infectious Diseases, Oslo University Hospital, 0424 Oslo, Norway

${ }^{8}$ Medical Department, Lovisen berg Diaconal Hospital, 0424 Oslo,

${ }^{9}$ Department of Research Support for Clinical Trials, Oslo University Hospital, 0424 Oslo, Norway

${ }^{10}$ Department of Haematology, Oslo University Hospital, 0424 Oslo, Norway

${ }^{11}$ Hospital Pharmacies, South-Eastern Norway Enterprise, 0050 Oslo, Norway

${ }^{12}$ Medical Department, Bærum Hospital, Vestre Viken Hospital Trust, 3004 Drammen, Norway

${ }^{13}$ Division of Medicine, Diakonhjemmet Hospital, 0319 Oslo, Norway

${ }^{14}$ Department of Infectious Diseases, Sørlandet Hospital SSK, 4604 Kristiansand, Norway

${ }^{15}$ Innlandet Hospital Trust, 2629 Lillehammer, Norway

${ }^{16}$ Department of Infectious Diseases, Stavanger University Hospital, 4068 Stavanger, Norway

${ }^{17}$ Department of Anesthesiology and Intensive Care, University Hospital of North Norway, 9019

Troms $\emptyset$, Norway

${ }^{18}$ Department of Infectious Diseases, Vestfold Hospital Trust, 3103 Tønsberg, Norway

${ }^{19}$ Department of Medicine, Ringerike Hospital, Vestre Viken Hospital Trust, 3511 Ringerike, Norway

${ }^{20}$ Division of infectious Diseases, Telemark Hospital Trust, 3710 Skien, Norway

${ }^{21}$ Department of Medicine, Haraldsplass Deaconess Hospital, 5892 Bergen, Norway

${ }^{22}$ Department of Anaesthesiology, Sorlandet Hospital, Arendal, Norway

${ }^{23}$ Department of Medicine, Innlandet Hospital Trust, Elverum, 2409 Elverum, Norway

${ }^{24}$ Department of Anesthesia and Intensive Care, Levanger Hospital, Nord-Trøndelag Hospital Trust, 7601 Levanger, Norway

${ }^{25}$ Department of Infectious Diseases, Trondheim University Hospital, 7006 Trondheim, Norway

${ }^{26}$ Department of Infectious Diseases, $\emptyset$ stfold Hospital Kalnes, 1714 Grålum, Norway

${ }^{27}$ Department of Anesthesia and Intensive Care, Haukeland University Hospital, 5021 Bergen, Norway

${ }^{28}$ Section of Gastroenterology, Department of Transplantation Medicine, Oslo University Hospital,

Oslo, Norway

${ }^{29}$ Section of Clinical Immunology and infectious Diseases, Oslo University Hospital, 0424 Oslo, Norway 
medRxiv preprint doi: https://doi.org/10.1101/2021.07.13.21260412; this version posted July 16, 2021. The copyright holder for this preprint (which was not certified by peer review) is the author/funder, who has granted medRxiv a license to display the preprint in perpetuity.

All rights reserved. No reuse allowed without permission.

Running Title: Gut microbiota and respiratory dysfunction in COVID-19

Word count: 3527

Key words: SARS CoV-2, microbiome, pulmonary function, NOR-Solidarity

Address correspondence: Marius Trøseid, marius.troseid@medisin.uio.no, +4792440240 
medRxiv preprint doi: https://doi.org/10.1101/2021.07.13.21260412; this version posted July 16, 2021. The copyright holder for this preprint

(which was not certified by peer review) is the author/funder, who has granted medRxiv a license to display the preprint in perpetuity.

All rights reserved. No reuse allowed without permission.

\section{Abstract}

Objective: Although COVID-19 is primarily a respiratory infection, mounting evidence suggests that the GI tract is involved in the disease, with gut barrier dysfunction and gut microbiota alterations being related to disease severity. Whether these alterations persist and could be related to long-term respiratory dysfunction is unknown.

Design: From the NOR-Solidarity trial $(n=181)$, plasma was collected during hospital admission and after three months, and analyzed for markers of gut barrier dysfunction and inflammation. At the three-month follow-up, pulmonary function was assessed by measuring diffusing capacity of the lungs for carbon monoxide ( $\mathrm{DL}_{\mathrm{CO}}$ ), and rectal swabs for gut microbiota analyses were collected ( $\mathrm{n}=$ 97) and analysed by sequencing of the $16 \mathrm{~S}$ rRNA gene.

Results: Gut microbiota diversity was reduced in COVID-19 patients with persistent respiratory dysfunction, defined as $\mathrm{DL}_{\mathrm{CO}}$ below lower limit of normal three months after hospitalization. These patients also had an altered global gut microbiota composition, with reduced abundance of Erysipelotrichaceae UCG-003 and increased abundance of Flavonifractor and Veillonella, the latter potentially being linked to fibrosis. During hospitalization, increased plasma levels of lipopolysaccharide-binding protein (LBP) were strongly associated with respiratory failure, defined as $\mathrm{pO}_{2} / \mathrm{fiO}_{2}-(\mathrm{P} / \mathrm{F}$-ratio $)<26.6 \mathrm{kPa}$. LBP levels remained elevated during and after hospitalization, and was associated with low-grade inflammation and persistent respiratory dysfunction after three months.

Conclusion: Persistent respiratory dysfunction after COVID-19 is associated with reduced biodiversity and gut microbiota alterations, along with persistently elevated LBP levels. Our results point to a potential gut-lung axis that should be further investigated in relation to long-term pulmonary dysfunction and long COVID. 


\section{Summary box:}

\section{What is already known about this subject?}

- Mounting evidence suggests that the gastrointestinal tract is involved in the pathogenesis of COVID-19, with the putative SARS-COV-2 receptor ACE 2 ubiquitously expressed in the gut.

- In severe COVID-19, the gut-blood barrier is compromised, and leakage of microbial products, such as lipopolysaccharides (LPS), could affect the host's response to COVID-19 infection.

- COVID-19 patients exhibit an altered gut microbiota composition, which has been related to disease severity. However, it is currently not known whether dysbiosis or gut barrier dysfunction persist long-term after hospitalization, or whether microbiota-related mechanisms could be related to persistent pulmonary dysfunction.

\section{What are the new findings?}

- COVID-19 patients with persistent respiratory dysfunction after three months had a lower microbial diversity and an altered gut microbiota composition at the same time point.

- The microbiota alterations included reduced abundance of Erysipelotrichaceae UCG-003 and increased abundance of Veillonella and Flavonifractor.

- During hospitalization, increased plasma levels of LBP were strongly associated with respiratory failure.

- LBP levels remained elevated during and after hospitalization, and associated significantly with persistent respiratory dysfunction at three-month follow-up.

\section{How might it impact on clinical practice in the foreseeable future?}

Our findings point to a potential gut-lung axis in relation not only to respiratory failure during hospitalization, but also to long-term COVID-19 morbidity. Further studies on gut microbiota composition and gut barrier dysfunction as potential treatment targets and/or disease severity biomarkers in relation to long-term pulmonary dysfunction and long COVID are warranted. 
medRxiv preprint doi: https://doi.org/10.1101/2021.07.13.21260412; this version posted July 16, 2021. The copyright holder for this preprint

(which was not certified by peer review) is the author/funder, who has granted medRxiv a license to display the preprint in perpetuity.

All rights reserved. No reuse allowed without permission.

\section{Introduction}

6 Although COVID-19 is primarily a viral respiratory disease, aberrant immune responses to the

7 causative virus, SARS-CoV-2, resulting in systemic inflammation and multi-organ involvement are

8 central features in severe and critical disease. In addition, mounting evidence suggests that the

9 gastrointestinal (GI) tract is involved in the pathogenesis of COVID-19(1,2). This includes the ability

of SARS-CoV-2 to infect and replicate within human small intestine enterocytes, with viral RNA being

11 detectable in fecal samples long time after symptom relief $(3,4)$.

12 The Gl tract is the largest immunological organ in the body, and its resident microbiota is known to modulate regional as well as systemic host immune responses. It has been hypothesized that the gut microbiota could be a mediator of host inflammatory immune responses during COVID-19 and thereby contribute to the pronounced systemic inflammation seen in patients requiring hospitalization $(5,6)$. In fact, angiotensin-converting enzyme (ACE) 2, the putative SARS-CoV-2 receptor, is ubiquitously expressed in several organs, including the gut, where ACE2 expression in enterocytes may serve as a site for enteric SARS-CoV-2 infection(7).

Recent studies suggest that severe SARS-CoV-2 infection could compromise the integrity of the gutblood barrier, leading to enhanced leakage of microbial products such as lipopolysaccharides (LPS), possibly affecting the host's response to COVID-19 through activation of the innate immune system $(3,8)$. In a small observational study of hospitalized COVID-19 patients, we recently reported that elevated plasma levels of LPS-binding protein (LBP) were associated with elevated cardiac markers(7). We also found elevated levels of the CCR9-ligand CCL25 in these patients, which is involved in gut homing of T cells(9). However, knowledge on the relationship between markers of gut barrier dysfunction and the degree of respiratory failure, and in particular persistently impaired pulmonary dysfunction following COVID-19 hospitalization, is scarce. alterations were recently found to be related to disease severity(10). Although these alterations 
medRxiv preprint doi: https://doi.org/10.1101/2021.07.13.21260412; this version posted July 16, 2021. The copyright holder for this preprint

(which was not certified by peer review) is the author/funder, who has granted medRxiv a license to display the preprint in perpetuity.

All rights reserved. No reuse allowed without permission.

30 persisted when investigated at median six days after a negative SARS-CoV-2 PCR test, it is currently

31 not known whether gut microbiota alterations or gut barrier dysfunction persist long-term after

32 hospitalization. Moreover, whether microbiota-related mechanisms could be involved in the

33 persistent inflammation and pulmonary dysfunction observed in some patients at follow-up after

34 hospitalization for COVID-19 is unknown.

35 The NOR-Solidarity trial is an independent add-on study to the WHO Solidarity trial(11), recently

36 reporting no effects of hydroxychloroquine (HCQ) or remdesivir compared to standard of care (SoC)

37 on clinical outcome, viral clearance or systemic inflammation in hospitalized COVID-19 patients(12).

38 In the present sub-study, we investigated whether gut microbiota collected three months after

39 hospital admission, as well markers of gut barrier dysfunction measured during and after

40 hospitalization, were related to persistent pulmonary dysfunction after COVID-19. 
medRxiv preprint doi: https://doi.org/10.1101/2021.07.13.21260412; this version posted July 16, 2021. The copyright holder for this preprint

(which was not certified by peer review) is the author/funder, who has granted medRxiv a license to display the preprint in perpetuity.

All rights reserved. No reuse allowed without permission.

\section{Methods}

43 Study design and participants

$44 \quad$ NOR-Solidarity is a multicentre, open label, adaptive randomised clinical trial evaluating the effect of antiviral drugs on hospitalized COVID-19 patients admitted to 23 Norwegian hospitals(12). In addition, NOR-Solidarity included collections of blood biobank and outpatient visits at a three-month follow-up after hospital admission. The study was approved by the Committee for Medical Research Ethics Region South East Norway (118684) and by the Norwegian Medicines Agency (20/04950-23) and registered in ClinicalTrials.gov (NCT04321616). Participants were included from March $28^{\text {th }}$ until protocol and included severe comorbidity (life expectancy $<3$ months), high levels of liver transaminases (AST/ALT > 5 times upper limit of normal), corrected QT interval time as assessed by ECG more than $470 \mathrm{~ms}$, pregnancy, breast feeding, acute comorbidity occurrence in a 7-day period before inclusion, known intolerance to study drugs, concomitant medications interfering with the study drugs or participation in a confounding trial(12). All participants gave informed consent prior to inclusion, either by themselves or a legally authorised representative.

\section{Intervention and outcomes}

In the NOR-Solidarity study ( $n=181$ ), participants were randomized and allocated to one of three treatment arms, 1) local SoC; 2) SoC plus $800 \mathrm{mg}$ of oral HCQ twice daily on day 1, then $400 \mathrm{mg}$ twice daily up to 9 days; or 3) SoC plus $200 \mathrm{mg}$ of intravenous remdesivir on day 1, then $100 \mathrm{mg}$ daily up to 9 days. All study treatments were stopped at hospital discharge. Since the interventions had no effect on clinical outcome, viral clearance or systemic inflammation(12), data from the different intervention arms were in this sub-study pooled for analyses to examine whether gut microbiota composition after three months and markers of gut barrier dysfunction during hospitalization and after three months had any effect on:(i) acute respiratory failure defined as $\mathrm{pO}_{2} / \mathrm{fiO}_{2}-(\mathrm{P} / \mathrm{F}$-ratio $)$ 
medRxiv preprint doi: https://doi.org/10.1101/2021.07.13.21260412; this version posted July 16, 2021. The copyright holder for this preprint

(which was not certified by peer review) is the author/funder, who has granted medRxiv a license to display the preprint in perpetuity.

All rights reserved. No reuse allowed without permission.

68

diffusing capacity of the lungs for carbon monoxide ( $\mathrm{DL}_{\mathrm{CO}}$ ) below the lower limit of normal (LLN) at the three-month follow-up. To ensure lack of influence of different treatment, data were also adjusted for treatment group.

\section{Circulating markers of gut barrier dysfunction}

Peripheral blood samples were drawn at admission, day three and day eight and then weekly until hospital discharge, as well as at outpatient follow-up at three months. Age- and sex-matched controls (Regional Committees for Medical and Health Research 2014/2078) were used as reference material. Plasma levels of LBP, intestinal fatty acid binding protein (IFABP), CCL25 and regenerating islet-derived protein $3 \alpha$ (REG-3 $\alpha$ ) were measured in duplicate by enzyme immunoassays (EIA) using commercially available antibodies (R\&D Systems, Minneapolis, MN) in a 384 format using a combination of a SELMA (Jena, Germany) pipetting robot and a BioTek (Winooski, VT) dispenser/washer. Absorption was read at $450 \mathrm{~nm}$ with wavelength correction set to $540 \mathrm{~nm}$ using an EIA plate reader (Bio-Rad, Hercules, CA). Intra- and inter-assay coefficients of variation were $<10 \%$.

\section{Three-month follow-up}

Three months after hospital admission, 149 participants attended a follow-up visit that included blood sampling for routine clinical biochemistry and biobanking(12). Rectal swabs were also collected from a sub-group of participants ( $n=97)$. Lung function tests ( $n=108)$, consisting of spirometry and diffusion capacity of the lungs for carbon monoxide ( $\left(\mathrm{LL}_{\mathrm{co}}\right)$, were performed at each participating center, and performed according to the European Respiratory Society's and the American Thoracic Society'a guidelines $(13,14)$, thoroughly described previously(15). Studies have shown that $\mathrm{DL}_{\mathrm{co}}$ is the pulmonary measure most frequently affected after hospitalization for COVID-19(15, 16), and for the purpose of this report, we chose $\mathrm{DL}_{\mathrm{co}}$ as a measure of pulmonary function. $\mathrm{DL}_{\mathrm{co}}$ in per cent of predicted and the lower limit of normal (LLN) were calculated according to the Global Lung Function 
medRxiv preprint doi: https://doi.org/10.1101/2021.07.13.21260412; this version posted July 16, 2021. The copyright holder for this preprint

(which was not certified by peer review) is the author/funder, who has granted medRxiv a license to display the preprint in perpetuity.

All rights reserved. No reuse allowed without permission.

92 Initiative Network (GLI)(17), as previously described(15). Of the 108 participants that underwent lung

93 function tests, 83 participants also had rectal swabs available.

\section{Gut microbiota analyses}

95 Rectal swabs were stored on a stabilizing transportation medium (soluble Amies, Thermo Scientific ${ }^{\mathrm{TM}}$ )

96 and frozen at $-80 \mathrm{C}$ until analysed. Fecal DNA was extracted using the QIAamp ${ }^{\oplus}$ PowerFecal ${ }^{\circledR}$ Pro DNA

97 Kit (Qiagen, Germany), with slight modifications. Briefly, $700 \mu \mathrm{L}$ of fecal material was pelleted and

homogenized in $800 \mu \mathrm{L}$ of kit solution CD1 using a bead-beater ( $2 \times 60 \mathrm{~s}$ at $5.5 \mathrm{~ms}$, room temperature),

and further processed according to the manufacturer's protocol. Libraries for 16S rRNA amplicon allowing for $300 \mathrm{bp}$ paired-end reads.

\section{Sequence processing and bioinformatics}

Paired-end reads containing Illumina Universal Adapters or PhiX were discarded using bbduk version 
medRxiv preprint doi: https://doi.org/10.1101/2021.07.13.21260412; this version posted July 16, 2021. The copyright holder for this preprint

(which was not certified by peer review) is the author/funder, who has granted medRxiv a license to display the preprint in perpetuity.

All rights reserved. No reuse allowed without permission.

117 qtrim=r trimq=15 maxlength=440 mininsert=390). The merged contigs were trimmed to $400 \mathrm{bp}$ and

118 denoised to ASVs (Amplicon Sequence Variants) with deblur(21) in QlIME2 version 2021.2(22).

119 Taxonomic classification of ASVs was done based on RESCRIPt(23) in QIIME2 using a naïve Bayes

120 classifier trained on the V3-V4 region of a preclustered version ( $99 \%$ sequence similarity) of the Silva

121 database version 138(24). Filtering of contaminants was done with the R package microDecon(25)

122 based on a negative extraction control sample, and ASVs from mitochondria, chloroplast or lacking

123 taxonomic annotation on order level were also removed. A de-novo phylogenetic tree was built in

124 QIIME2 based on the remaining ASVs. To reduce the effect of uneven sequencing depths, samples

125 were rarefied (subsampled without replacement) to an even level of 7123 counts per sample and all

126 diversity analyses were performed on this rarefied dataset. Alpha diversity metrics (Observed ASVs

127 and Faith's phylogenetic diversity, PD) and beta diversity metrics (Bray-Curtis dissimilarity) were

128 calculated in QIIME2. Beta diversity comparisons were done with a permutational multivariate

129 analysis of variance test (Permanova). Differential abundance testing with LEfSe(26) was done on the

130 rarefied dataset, while for differential abundance testing with ALDEx2(27), a prevalence-filtered (25\%

131 most prevalent) version of the non-rarefied dataset was used.

132 Statistical analyses

133 Baseline characteristics were described by median (25th and 75th percentile (IQR)) for continuous

134 variables and percentages for categorical variables. Predefined outcomes (acute respiratory failure

135 defined as P/F-ratio <26.6 kPa during hospitalization and persistent respiratory dysfunction defined

136 as $\mathrm{DL}_{\mathrm{CO}}<\mathrm{LLN}$ after 3 months follow-up) were used as dichotomous variables. Analysis of clinical

137 characteristics at hospital admission (Fig. 4) according to acute respiratory failure was analyzed by

138 receiver operating characteristic (ROC) analysis and precision-recall curves were assessed, as the

139 outcome groups were unbalanced. IFABP, CCL25 and LBP were non-normally distributed and

140 transformed using log10 for comparisons between groups with the linear mixed model analysis, with

141 subject as random effect and time and respiratory failure as fixed effects (also as interaction).

142 Treatment was included as a covariate. Multivariate analysis of LBP in relation to respiratory failure 
medRxiv preprint doi: https://doi.org/10.1101/2021.07.13.21260412; this version posted July 16, 2021. The copyright holder for this preprint

(which was not certified by peer review) is the author/funder, who has granted medRxiv a license to display the preprint in perpetuity.

All rights reserved. No reuse allowed without permission.

143 was performed by binary logistic regression, adjusting for the covariates age, gender, treatment and

144 known comorbidities in the base model. Correlation analyses were performed with Spearman's rho

145 ( $\rho)$ due to skewed distribution of data. P-values are two-sided and considered significant when $<0.05$.

146 Group comparison of LBP levels in relation to persistent respiratory dysfunction was performed using

147 parametric t-test of log10-transformed data. SPSS release 26.0.0.1 and 27.0.0.0 were used for

148 statistical analysis.

149 Results

150 Baseline characteristics

151 NOR-Solidarity trial design and main results have recently been published(12). A total of 181

152 randomized patients were included in the present study and 149 completed the three months

153 follow-up, of which 108 performed pulmonary function testing and 97 had collected rectal swab for

154 gut microbiota analyses (Fig. 1). Baseline characteristics for the main study group and for the

155 microbiota sub-group are given in Table 1. In the main study group, participants were on average 59

156 years, mostly male (66\%), and the median body mass index (BMI) was $27.4 \mathrm{~kg} / \mathrm{m}^{2}$ (27\% obese, BMI >

$15730 \mathrm{~kg} / \mathrm{m}^{2}$ ). Use of antibiotics during hospitalization was reported in $48 \%$ of the participants, and $68 \%$

158 reported any known comorbidities, with hypertension (31\%), obesity (27\%) and diabetes mellitus

$159(17 \%)$ as the most common. Only six per cent reported presence of chronic pulmonary disease.

Table 1. Baseline characteristics

\begin{tabular}{lcc}
\hline & $\begin{array}{c}\text { Main study group } \\
\text { (n=181) }\end{array}$ & $\begin{array}{c}\text { Microbiota sub-group } \\
\text { (n=97) }\end{array}$ \\
\hline Age, years & $59(50.0-71.0)$ & $57(48.0-65.0)$ \\
Male gender (\%) & $119(66)$ & $60(62)$ \\
Body Mass Index, kg/m2 & $27.4(24.7-30.9)$ & $27.7(25.0-31.6)$ \\
Antibiotics use (\%) & $87(48)$ & $41(42)$ \\
Treatment group & & \\
$\quad$ Standard of Care (SoC) (\%) & $87(48)$ & $47(49)$ \\
SoC + Hydroxychloroquine (\%) & $52(29)$ & $33(34)$ \\
$\quad$ SoC + Remdesivir (\%) & $42(23)$ & $17(18)$ \\
Comorbidities & & \\
$\quad$ Any known comorbidities (\%) & $122(68)$ & $66(68)$ \\
$\quad$ Chronic pulmonary disease (\%) & $10(6)$ & $5(5)$
\end{tabular}


medRxiv preprint doi: https://doi.org/10.1101/2021.07.13.21260412; this version posted July 16, 2021. The copyright holder for this preprint (which was not certified by peer review) is the author/funder, who has granted medRxiv a license to display the preprint in perpetuity.

All rights reserved. No reuse allowed without permission.

160

161

162

163

164

165

166

167

168

169

170

171

172

173

174

175

176

177
Hypertension (\%)

Chronic cardiac disease (\%)

Diabetes mellitus (\%)

Obesity, BMI > $30 \mathrm{~kg} / \mathrm{m} 2$ (\%)

$\mathrm{P} / \mathrm{F}$-ratio at admission, $\mathrm{kPa}$

C-reactive protein, $\mathrm{mg} / \mathrm{L}$

White blood cell count, $\times 10^{9} / \mathrm{L}$

Neutrophil count, $\times 10^{9} / \mathrm{L}$

Ferritin, $\mu \mathrm{g} / \mathrm{L}$

D-dimer, $\mathrm{mg} / \mathrm{L}$

Virus load $\left(\log _{10 / 1000}\right)$

Lipopolysaccharide-binding protein $(\mu \mathrm{g} / \mathrm{mL}$ )
$55(31)$

28 (16)

$31(17)$

$44(27)$

$42.1(32.0-48.1)$

$70.0(36.3-70.0)$

$6.2(4.7-8.6)$

$4.3(3.0-6.6)$

$626(325-1209)$

$0.7(0.5-1.2)$

$1.9(0.7-3.1)$

$16.3(8.5-26.1)$
$28(29)$

$12(12)$

$19(20)$

$28(30)$

$42.4(33.4-49.6)$

$66.0(33.5-122.5)$

$5.8(4.3-7.6)$

$3.7(2.4-6.2)$

$608(298-1017)$

$0.7(0.4-1.1)$

$1.7(0.0-2.9)$

$17.1(7.3-26.3)$

Results are shown as median values (25th-75th percentile) unless otherwise specified.

Respiratory dysfunction after three months is associated with altered gut microbiota composition and reduced bacterial diversity in previously hospitalized COVID-19 patients

At the three-month follow-up, 25 out of the 83 (30\%) previously hospitalized COVID-19 patients with rectal swabs and $\mathrm{DL}_{\mathrm{CO}}$ measurements available, had respiratory dysfunction defined as $\mathrm{DL}_{\mathrm{CO}}<\mathrm{LLN}$.

Notably, these patients had an altered global gut microbiota composition assessed by beta diversity (Bray Curtis (Fig. 2A)). Importantly, patients who received antibiotics during hospitalization had overlapping global microbiota composition with those not receiving antibiotics (Fig. 2B). Moreover, there was no statistical interaction between antibiotics use during hospitalization and the association between global microbiota composition and respiratory dysfunction at the three-month follow up.

Patients with respiratory dysfunction three months after hospital admission also had reduced bacterial alpha diversity (Observed ASVs and Faith's PD) compared to patients with respiratory function in the normal range (Fig. 2C-D). However, alpha diversity measures did not associate with age, gender, comorbidities, BMI, treatment groups, viral load or antibiotics use.

On taxonomic level, screening analysis using LEfSe suggested that respiratory dysfunction after three months was associated with increased relative abundances of five taxa and reduced relative 
medRxiv preprint doi: https://doi.org/10.1101/2021.07.13.21260412; this version posted July 16, 2021. The copyright holder for this preprint (which was not certified by peer review) is the author/funder, who has granted medRxiv a license to display the preprint in perpetuity.

All rights reserved. No reuse allowed without permission.

abundances of 20 taxa (Fig. 3A-B), including Erysipelotrichaceae UCG-003, and also several members of the Lachnospiraceae and Ruminococcaceae families, which are known producers of butyrate, the main energy source for enterocytes. We subsequently performed the same analysis using the ALDEx2 algorithm (filtered to $p<0.05$ ), reducing the number of genera identified by both LEfSe and ALDEx2 as associated with respiratory dysfunction to three; reduced abundance of Erysipelotrichaceae UCG003, and increased abundance of Veillonella and Flavonifractor (Fig. 3C). The largest effect size and lowest $p$-value from ALDEx2 was found for Veillonella, an anaerobic opportunistic pathogen, previously reported increased in COVID-19 patients (4) and associated with tissue fibrosis(28).

\section{Circulating markers of gut barrier dysfunction in relation to acute respiratory failure during} hospitalization

As microbiota traits associated with persistent respiratory dysfunction were potentially related to reduced capacity for butyrate production, which is vital for a functional gut barrier, we hypothesized that gut barrier dysfunction could be related to respiratory failure also in acute COVID-19. As microbiota samples from the acute phase of disease were not available, we explored whether circulating markers of gut barrier dysfunction were associated with acute respiratory failure defined as $\mathrm{P} / \mathrm{F}$ ratio $<26.6 \mathrm{kPa}$, which occurred in 60 patients $(33 \%)$ during hospitalization. As depicted in Fig. 4, levels of LBP discriminated clearly in ROC analyses (AUC 0.72), whereas CCL25, REG-3 $\alpha$ and IFABP did not provide prognostic information (AUC between 0.62 and 0.51 ). However, as shown in the in the precison-recall curve (Fig. 4B), only around 60\% (recall) of the patients with acute respiratory failure would be identified with only around $55 \%$ (precision) being true positives. In multivariate logistic regression adjusting for age, gender, comorbidity and treatment, LBP was associated with acute respiratory failure during hospitalization (adjusted OR (aOR) 6.3 [1.5-27]). Further adjusting for antibiotics use had little impact on the association (aOR 4.6 [1.0-21]).

\section{Temporal changes in markers of gut barrier dysfunction during hospitalization}


medRxiv preprint doi: https://doi.org/10.1101/2021.07.13.21260412; this version posted July 16, 2021. The copyright holder for this preprint

(which was not certified by peer review) is the author/funder, who has granted medRxiv a license to display the preprint in perpetuity.

All rights reserved. No reuse allowed without permission.

204 LBP levels remained consistently elevated during hospitalization in patients with acute respiratory

205 failure compared to patients without respiratory failure (Fig. 5A). However, whereas LBP levels

206 showed a declining trend over time, the opposite was observed for REG-3 $\alpha$ (Fig. 5D), a bactericidal C-

207 type lectin with protective antibacterial properties, produced in the intestine. REG-3 $\alpha$ increased

during hospitalization, but only in patients with respiratory failure. No changes were observed for

IFABP or CCL25 during hospitalization (Fig. 5B-C).

210

The association of LBP with persistent respiratory dysfunction and inflammation

Notably, LBP levels after three months were higher in patients with respiratory dysfunction

$\left(\mathrm{DL}_{\mathrm{CO}}<\mathrm{LLN}\right)$ (Supplementary Figure 1), and negatively correlated with per cent predicted values of

$\operatorname{DL}_{\mathrm{CO}}(\rho-0.27, p=0.031)$. Of note, we found no correlation between LBP and measures of microbiota

diversity in the subgroup with both available. Plasma levels of LBP at admission and after three

months were significantly associated with several clinical markers of systemic inflammation,

relating gut leakage to persistent systemic inflammation even several months after hospitalization.

\section{Discussion}

In this sub-study of the NOR-Solidarity trial, we investigated a potential gut-lung axis during and after 
medRxiv preprint doi: https://doi.org/10.1101/2021.07.13.21260412; this version posted July 16, 2021. The copyright holder for this preprint

(which was not certified by peer review) is the author/funder, who has granted medRxiv a license to display the preprint in perpetuity.

All rights reserved. No reuse allowed without permission.

228

associated with persistent low-grade inflammation and respiratory dysfunction at the three-month follow-up.

In a recent report, Yeoh et al reported downregulation of several gut commensals with known immunomodulatory potential in COVID-19 patients, including Faecalibacterium prausnitzii and Eubacterium rectale, which remained low in samples collected up to 30 days after disease resolution(10). Herein, we extend these findings by showing that altered gut microbiota, including decreased alpha diversity three months after hospital admission was associated with impaired pulmonary function at this time point. We also found that several members of the Lachnospiraceae and Ruminococcaceae families, such as Coprococcus and Ruminococcus, known producers of butyrate, were reduced in COVID-19 patients with pulmonary impairment after three months. Butyrate has local immunomodulatory effects in the gut mucosa, and as the main energy substrate for enterocytes, it is vital for gut barrier maintenance(29). Interestingly, LBP levels as an indirect marker of gut leakage were associated with impaired pulmonary function, not only during hospitalization (P/F-ratio $<26.6 \mathrm{kPa}$; respiratory failure), but also after three months (inverse correlation with $\left.\mathrm{DL}_{\mathrm{co}}\right)$.

Of interest, the COVID-related dysbiosis reported by Yeoh et al correlated with several inflammatory markers, in line with our finding of LBP being associated with acute inflammation during hospitalization. Notably, we now show that LBP levels are associated with persistent low-grade inflammation even after three months. A potential role of gut barrier dysfunction as a driver for the multisystem inflammatory syndrome occurring in pediatric COVID-19 was recently reported(30), and our findings suggest that similar mechanisms could be relevant in adult patients. Whereas LBP levels showed a declining trend over time, the opposite was observed for REG-3 $\alpha$, which increased during hospitalization, but only in patients with respiratory failure. REG-3 $\alpha$ is a bactericidal C-type lectin produced in the intestine, with antibacterial properties against Gram positive bacteria, and with a role in maintaining a functional barrier between the gut mucosa and the gut microbial content(31). 
medRxiv preprint doi: https://doi.org/10.1101/2021.07.13.21260412; this version posted July 16, 2021. The copyright holder for this preprint

(which was not certified by peer review) is the author/funder, who has granted medRxiv a license to display the preprint in perpetuity.

All rights reserved. No reuse allowed without permission.

253 Hence, a potential interpretation of our findings could be that both elevated LBP levels and

254 downregulation of REG-3 $\alpha$ at admission might reflect an impaired gut barrier. In some chronic

255 inflammatory conditions related to immunodeficiencies, we have also seen a direct correlation

256 between microbiota composition and markers of gut barrier function $(32,33)$, but this was not seen

257 in the COVID-19 patients at three months. To what degree gut microbiota alterations are directly

258 influencing the gut barrier, is therefore uncertain.

Other microbiota related traits could also be relevant. The largest effect size observed in patients

with persistent pulmonary dysfunction was the increased relative abundance of Veillonella, which

has previously been linked to several disease states of the lung and liver where fibrosis is central to

the pathogenesis $(28,34,35)$. Interestingly, increased relative abundance of Veillonella in COVID-19

patients was also recently reported by Tao et al(36).However, whether this bacterial genus could be

relevant for fibrosis development after COVID-19, either as a contributing factor or as a consequence

of a fibrotic process, cannot be answered in an observational study.

Whether the observed alterations in microbiota composition and gut leakage markers in this trial are related to COVID-19 per se or mirror other factors, such as comorbidities and treatment, is not clear.

In multivariate analyses, LBP was strongly associated with acute respiratory failure after adjustment

for age, gender, treatment, comorbidities and use of antibiotics. LBP is an acute phase protein 
medRxiv preprint doi: https://doi.org/10.1101/2021.07.13.21260412; this version posted July 16, 2021. The copyright holder for this preprint

(which was not certified by peer review) is the author/funder, who has granted medRxiv a license to display the preprint in perpetuity.

All rights reserved. No reuse allowed without permission.

278 performed in one cohort, and without a validation panel these must be considered explorative.

279 Moreover, pulmonary function tests beyond P/F-ratio were only performed at three-month follow-

280 up, eliminating the possibility for baseline comparisons. The study also has obvious strengths,

281 including standardized data capture in a randomized trial with longitudinal biobanking, as well as

282 comprehensive long-term follow-up with blood tests, microbiota sampling and assessment of

283 pulmonary function by $\mathrm{DL}_{\mathrm{CO}}$. Also, to our knowledge, our study is the first to link pulmonary function

284 to gut microbiota alterations in COVID-19.

In conclusion, the decreased microbial diversity and compositional gut microbiota alterations in

patients with persistent respiratory dysfunction, as well as the association of persistently raised LBP

levels with these clinical features, point to a potential gut-lung axis in COVID-19. These observations

could be related to not only acute respiratory failure during hospitalization, but also to long-term

COVID-19 morbidity. Our findings warrant further research on the potential role of gut microbiota

composition and gut barrier dysfunction in relation to long-term pulmonary dysfunction and long

COVID.

\section{Acknowledgements}

We thank WHO Solidarity and NOR-Solidarity study groups for the opportunity to perform this add-

on study. We would also like to thank Karoline Hansen Skåra and Azita Rashidi at the Institute of

to the viral analysis data.

\section{Conflicts of interest}

300 All authors declare no competing interest.

\section{$301 \quad$ Funding}


medRxiv preprint doi: https://doi.org/10.1101/2021.07.13.21260412; this version posted July 16, 2021. The copyright holder for this preprint

(which was not certified by peer review) is the author/funder, who has granted medRxiv a license to display the preprint in perpetuity.

All rights reserved. No reuse allowed without permission.

302 The study was funded by the National Clinical Therapy Research in the Specialist Health Services

303 (KLINBEFORSK), Norway and South-Eastern Norway Regional Health Authority (grant number

304 2021071). The microbiota analyses were funded by the strategic research area "Personalized

305 microbiota therapy in clinical medicine" at Oslo University Hospital. The funders had no role in study

306 design, data collection, data analysis, data interpretation, or writing of the report. The corresponding

307 author had full access to all the data in the study and had final responsibility for the decision to

308 submit for publication.

\section{Contributions}

$310 \mathrm{BV}, \mathrm{TU}, \mathrm{PA}, \mathrm{JRH}$ and $\mathrm{MT}$ were responsible for the study conception and execution of the present

311 substudy. ABD, TK, ICO, AMDR, KNH, PA and MT were responsible for the management,

312 coordination, research activity planning and execution of the NOR-Solidarity trial. TL and OHS were

313 responsible for the three-month follow-up protocol for pulmonary function. TBD, ABD, BH, TR and PA

314 coordinated the collection and storage of the biobank material. AMDR, BS, KT, HH, AT, RM, MH, RE,

$315 \AA ̊ \mathrm{~B}, \mathrm{ABK}, \mathrm{AJ}, \mathrm{LT}, \mathrm{HS}, \mathrm{BRK}, \mathrm{RBO}, \mathrm{CMY}, \mathrm{NVS}, \mathrm{RH}, \mathrm{SA}$ and $\mathrm{BB}$ were locally responsible for conducting the

316 trial at the various included hospitals providing rectal swab material. BV performed the DNA

317 extraction and library preparation of microbiota samples. TU, TL and AEM performed the gut leakage

318 marker analyses. BV and TU performed the statistical analyses. KH performed the bioinformatics

319 analyses of microbiota data. BV and MT drafted the manuscript. TU, ABD, PA and JRH critically

320 revised the manuscript. All authors revised and approved the final version of the manuscript. 
medRxiv preprint doi: https://doi.org/10.1101/2021.07.13.21260412; this version posted July 16, 2021. The copyright holder for this preprint (which was not certified by peer review) is the author/funder, who has granted medRxiv a license to display the preprint in perpetuity.

All rights reserved. No reuse allowed without permission.

\section{Figure legends}

323 Figure 1. Flow-chart of patients included in the present add-on study based on the original NOR-

324 Solidarity study protocol.

Figure 2. Gut microbiota diversity in patients with or without persistent respiratory dysfunction at the three-month follow-up. Beta diversity by principal coordinate analysis showing Bray-Curtis distances separating patients with or without respiratory dysfunction (DLCO<LLN, $n=83$ ) (A), with overlapping microbiota composition in relation to antibiotics use (B). Alpha diversity measured by observed ASVs (C) and Faith 's PD (D) in patients with or without respiratory dysfunction. Abbreviations: ASVs, amplicon sequence variants; PD, phylogenetic diversity.

Figure 3. Gut microbial composition in patients with persistent respiratory dysfunction at the threemonth follow-up (DLCO<LLN, n=83). A) LDA score of taxa abundance differences using LEfSe analysis. from ALDEx2 analysis showing effect size (difference between groups divided by dispersion within groups, on log2-scale) by p-value of differentially abundant genera. Abbreviations: LDA, linear discriminant analysis; LEfSe, linear discriminant analysis effect size.

Figure 4. Admission levels ( $n=144$ ) of markers of gut barrier dysfunction in relation to acute respiratory failure $(\mathrm{n}=44)$ during hospitalization ( $\mathrm{P} / \mathrm{F}$-ratio $<26.6 \mathrm{kPa}$ ). A) ROC analysis and $\mathrm{B}$ ) precision-recall curves for LBP (brown), IFABP (green), CCL25 (blue) and REG-3 $\alpha$ (orange). The numbers shown in A) are the AUC from the ROC-analysis ***p<0.001. Abbreviations: LBP, lipopolysaccharide-binding protein; IFABP, intestinal-type fatty acid-binding protein; CCL25, chemokine (C-C motif) ligand 25; REG-3 $\alpha$, regenerating islet-derived protein 3 alpha; ROC, receiver operating characteristic; AUC, area under the curve.

Figure 5. Temporal profile of markers of gut barrier dysfunction in relation to acute respiratory 
medRxiv preprint doi: https://doi.org/10.1101/2021.07.13.21260412; this version posted July 16, 2021. The copyright holder for this preprint (which was not certified by peer review) is the author/funder, who has granted medRxiv a license to display the preprint in perpetuity. All rights reserved. No reuse allowed without permission.

346 yellow $p$-values reflect the effect RF from the repeated measures regression analysis, while the blue

$347 p$-values reflect the interaction between time and RF. Blue areas reflect levels in age- and sex-

348 matched healthy controls ( $n=24)$. Observations per time point: $B L, n=144 ; 3-5$ days, $n=134 ; 7-10$ days,

$349 n=84$. Abbreviations: LBP, lipopolysaccharide-binding protein; IFABP, intestinal-type fatty acid-

350 binding protein; CCL25, chemokine (C-C motif) ligand 25; REG-3 $\alpha$, regenerating islet-derived protein 3

351 alpha; $R F$, respiratory failure.

352

353 
medRxiv preprint doi: https://doi.org/10.1101/2021.07.13.21260412; this version posted July 16, 2021. The copyright holder for this preprint (which was not certified by peer review) is the author/funder, who has granted medRxiv a license to display the preprint in perpetuity.

All rights reserved. No reuse allowed without permission.

1. Galanopoulos M, Gkeros F, Doukatas A, et al. COVID-19 pandemic: Pathophysiology and manifestations from the gastrointestinal tract. World J Gastroenterol 2020;26(31):4579-88.

2. Tabary M, Khanmohammadi S, Araghi F, et al. Pathologic features of COVID-19: A concise review. Pathol Res Pract 2020;216(9):153097.

3. Zuo T, Zhang F, Lui GCY, et al. Alterations in Gut Microbiota of Patients With COVID-19 During Time of Hospitalization. Gastroenterology 2020;159(3):944-55 e8.

4. Gu S, Chen Y, Wu Z, et al. Alterations of the Gut Microbiota in Patients With Coronavirus Disease 2019 or H1N1 Influenza. Clin Infect Dis 2020;71(10):2669-78.

5. Ferreira C, Viana SD, Reis F. Gut Microbiota Dysbiosis-Immune Hyperresponse-Inflammation Triad in Coronavirus Disease 2019 (COVID-19): Impact of Pharmacological and Nutraceutical Approaches. Microorganisms 2020;8(10). 6. Vignesh R, Swathirajan CR, Tun ZH, et al. Could Perturbation of Gut Microbiota Possibly Exacerbate the Severity of COVID-19 via Cytokine Storm? Front Immunol 2020;11:607734.

7. Hoel H, Heggelund L, Reikvam DH, et al. Elevated markers of gut leakage and inflammasome activation in COVID-19 patients with cardiac involvement. J Intern Med 2021;289(4):523-31.

8. Giron LB, Dweep H, Yin X, et al. Plasma Markers of Disrupted Gut Permeability in Severe COVID-19 Patients. Front Immunol 2021;12:686240.

9. Campbell DJ, Butcher EC. Intestinal attraction: CCL25 functions in effector lymphocyte recruitment to the small intestine. J Clin Invest 2002;110(8):1079-81.

10. Yeoh YK, Zuo T, Lui GC, et al. Gut microbiota composition reflects disease severity and dysfunctional immune responses in patients with COVID-19. Gut 2021;70(4):698-706.

11. Pan H, Peto R, Henao-Restrepo AM, et al. Repurposed Antiviral Drugs for Covid-19 - Interim WHO Solidarity Trial Results. N Engl J Med 2021;384(6):497-511.

12. Barratt-Due A, Olsen IC, Nezvalova-Henriksen K, et al. Evaluation of the Effects of Remdesivir and Hydroxychloroquine on Viral Clearance in COVID-19 : A Randomized Trial. Ann Intern Med [Internet]. $2021 \mathrm{Jul} 13 ; 10.7326 / \mathrm{m} 21-0653$.

13. Graham BL, Brusasco V, Burgos F, et al. 2017 ERS/ATS standards for single-breath carbon monoxide uptake in the lung. Eur Respir J 2017;49(1).

14. Graham BL, Steenbruggen I, Miller MR, et al. Standardization of Spirometry 2019 Update. An Official American Thoracic Society and European Respiratory Society Technical Statement. Am J Respir Crit Care Med 2019;200(8):e70-e88.

15. Lerum TV, Aalokken TM, Bronstad E, et al. Dyspnoea, lung function and CT findings 3 months after hospital admission for COVID-19. Eur Respir J 2021;57(4).

16. Guler SA, Ebner L, Aubry-Beigelman C, et al. Pulmonary function and radiological features 4 months after COVID-19: first results from the national prospective observational Swiss COVID-19 lung study. Eur Respir J 2021;57(4).

17. Stanojevic S, Graham BL, Cooper BG, et al. Official ERS technical standards: Global Lung Function Initiative reference values for the carbon monoxide transfer factor for Caucasians. Eur Respir J 2017;50(3).

18. Fadrosh DW, Ma B, Gajer P, et al. An improved dual-indexing approach for multiplexed $16 \mathrm{~S}$ rRNA gene sequencing on the Illumina MiSeq platform. Microbiome 2014;2(1):6.

19. Martin M. Cutadapt removes adapter sequences from high-throughput sequencing reads. 2011 2011;17(1):3.

20. Bushnell B, Rood J, Singer E. BBMerge - Accurate paired shotgun read merging via overlap. PLoS One 2017;12(10):e0185056.

21. Amir A, McDonald D, Navas-Molina JA, et al. Deblur Rapidly Resolves Single-Nucleotide Community Sequence Patterns. mSystems 2017;2(2).

22. Bolyen $\mathrm{E}$, Rideout JR, Dillon MR, et al. Reproducible, interactive, scalable and extensible microbiome data science using QIIME 2. Nat Biotechnol 2019;37(8):852-7.

23. Robeson MS, O'Rourke DR, Kaehler BD, et al. RESCRIPt: Reproducible sequence taxonomy reference database management for the masses. bioRxiv 2020:2020.10.05.326504. 
medRxiv preprint doi: https://doi.org/10.1101/2021.07.13.21260412; this version posted July 16, 2021. The copyright holder for this preprint

(which was not certified by peer review) is the author/funder, who has granted medRxiv a license to display the preprint in perpetuity.

All rights reserved. No reuse allowed without permission.

406 24. Quast C, Pruesse E, Yilmaz P, et al. The SILVA ribosomal RNA gene database project:

407 improved data processing and web-based tools. Nucleic Acids Res 2013;41(Database issue):D590-6.

408 25. McKnight DT, Huerlimann R, Bower DS, et al. microDecon: A highly accurate read-subtraction

409 tool for the post-sequencing removal of contamination in metabarcoding studies. Environmental

410 DNA 2019;1(1):14-25.

411 26. Segata N, Izard J, Waldron L, et al. Metagenomic biomarker discovery and explanation.

412 Genome Biol 2011;12(6):R60.

413 27. Fernandes AD, Macklaim JM, Linn TG, et al. ANOVA-like differential expression (ALDEx)

414 analysis for mixed population RNA-Seq. PLoS One 2013;8(7):e67019.

415 28. Kummen M, Holm K, Anmarkrud JA, et al. The gut microbial profile in patients with primary

416 sclerosing cholangitis is distinct from patients with ulcerative colitis without biliary disease and

417 healthy controls. Gut 2017;66(4):611-9.

418 29. Gelpi M, Vestad B, Hansen SH, et al. Impact of Human Immunodeficiency Virus-Related Gut 419 Microbiota Alterations on Metabolic Comorbid Conditions. Clin Infect Dis 2020.

420 30. Yonker LM, Gilboa T, Ogata AF, et al. Multisystem inflammatory syndrome in children is 421 driven by zonulin-dependent loss of gut mucosal barrier. J Clin Invest 2021.

422 31. Mukherjee S, Hooper LV. Antimicrobial defense of the intestine. Immunity 2015;42(1):28-39.

423 32. Nowak P, Troseid M, Avershina E, et al. Gut microbiota diversity predicts immune status in

424 HIV-1 infection. AIDS 2015;29(18):2409-18.

425 33. Jorgensen SF, Troseid M, Kummen M, et al. Altered gut microbiota profile in common

426 variable immunodeficiency associates with levels of lipopolysaccharide and markers of systemic

427 immune activation. Mucosal Immunol 2016;9(6):1455-65.

428 34. Thavamani A, Salem I, Sferra TJ, et al. Impact of Altered Gut Microbiota and Its Metabolites in 429 Cystic Fibrosis. Metabolites 2021;11(2).

$430 \quad 35 . \quad$ Enaud R, Hooks KB, Barre A, et al. Intestinal Inflammation in Children with Cystic Fibrosis Is

431 Associated with Crohn's-Like Microbiota Disturbances. J Clin Med 2019;8(5).

432 36. Tao W, Zhang G, Wang X, et al. Analysis of the intestinal microbiota in COVID-19 patients and

433 its correlation with the inflammatory factor IL-18. Medicine in Microecology 2020;5:100023-.

434 37. Zweigner J, Schumann RR, Weber JR. The role of lipopolysaccharide-binding protein in

435 modulating the innate immune response. Microbes Infect 2006;8(3):946-52.

436 
Hospitalized COVID-19 patients

NOR-Solidarity study

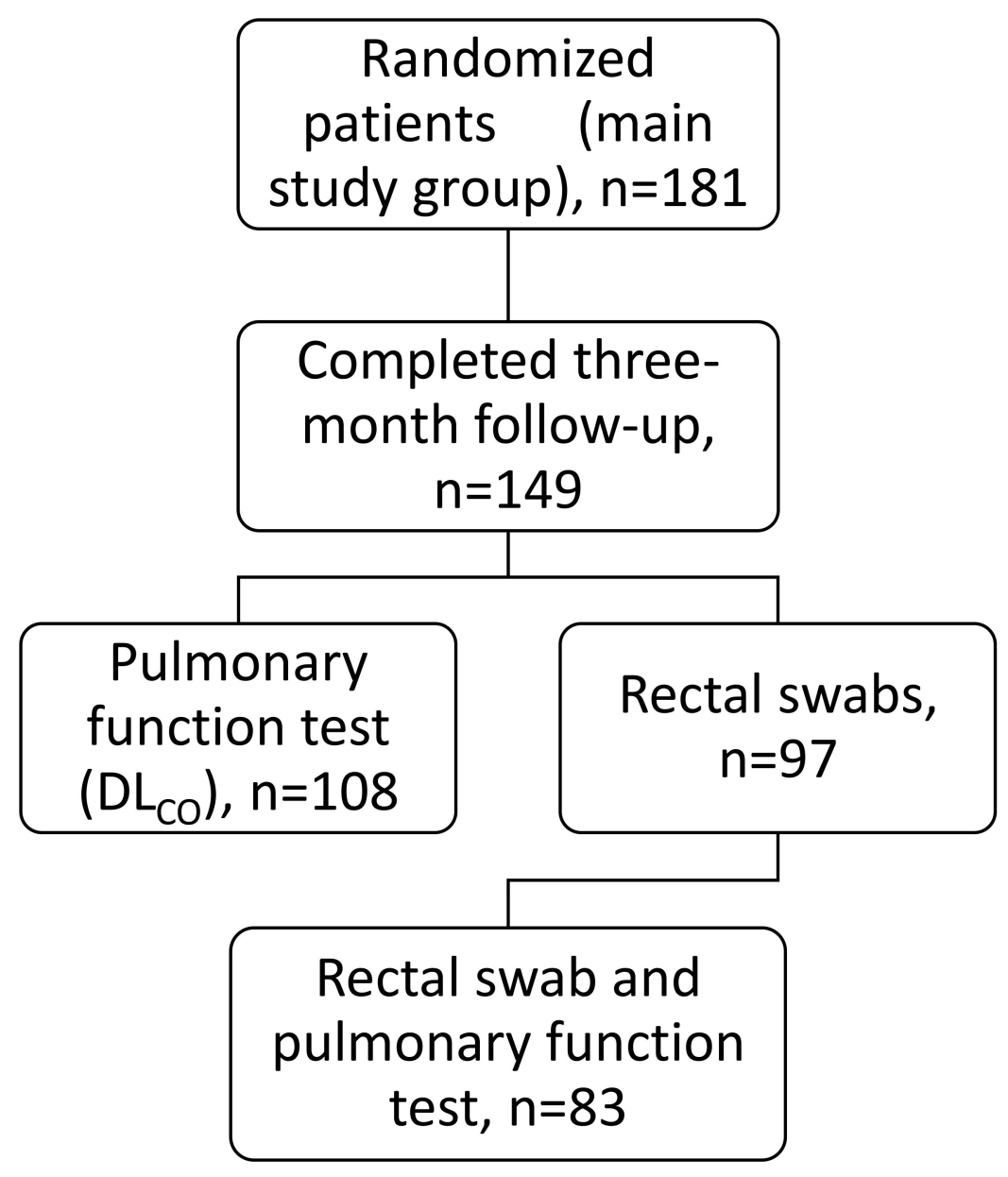


A Persistent respiratory dysfunction
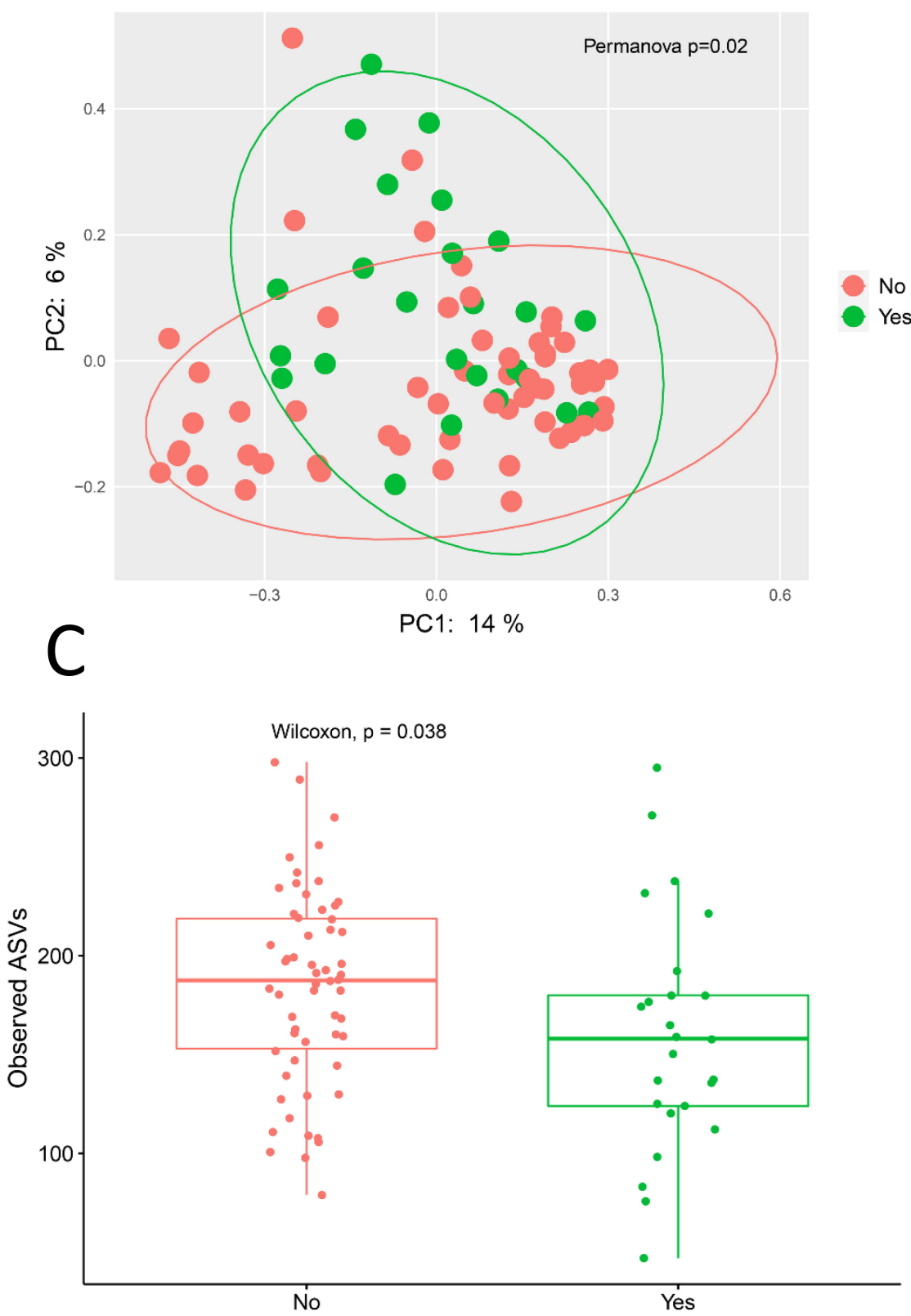

Persistent respiratory dysfunction
B Antibiotics use
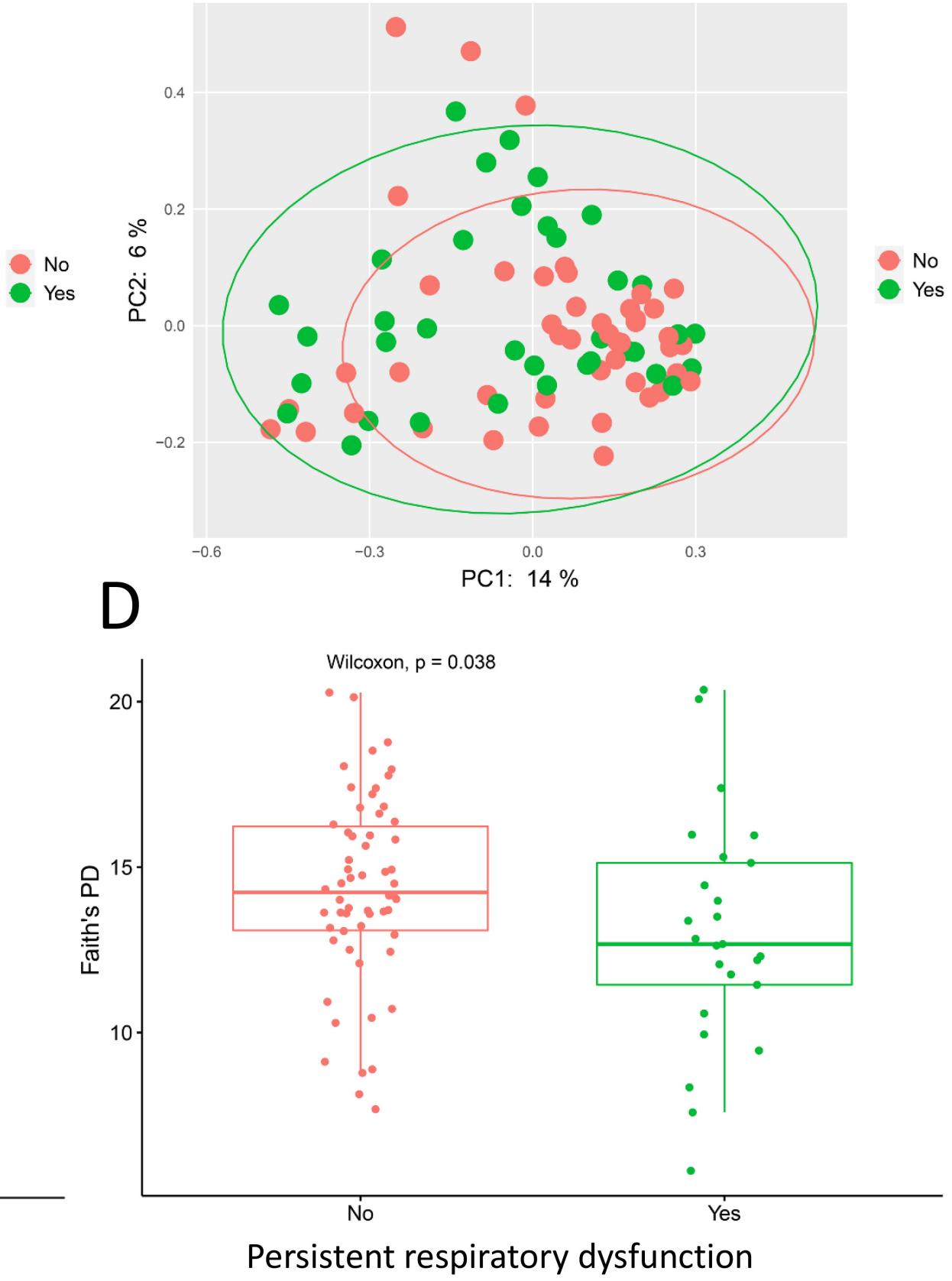

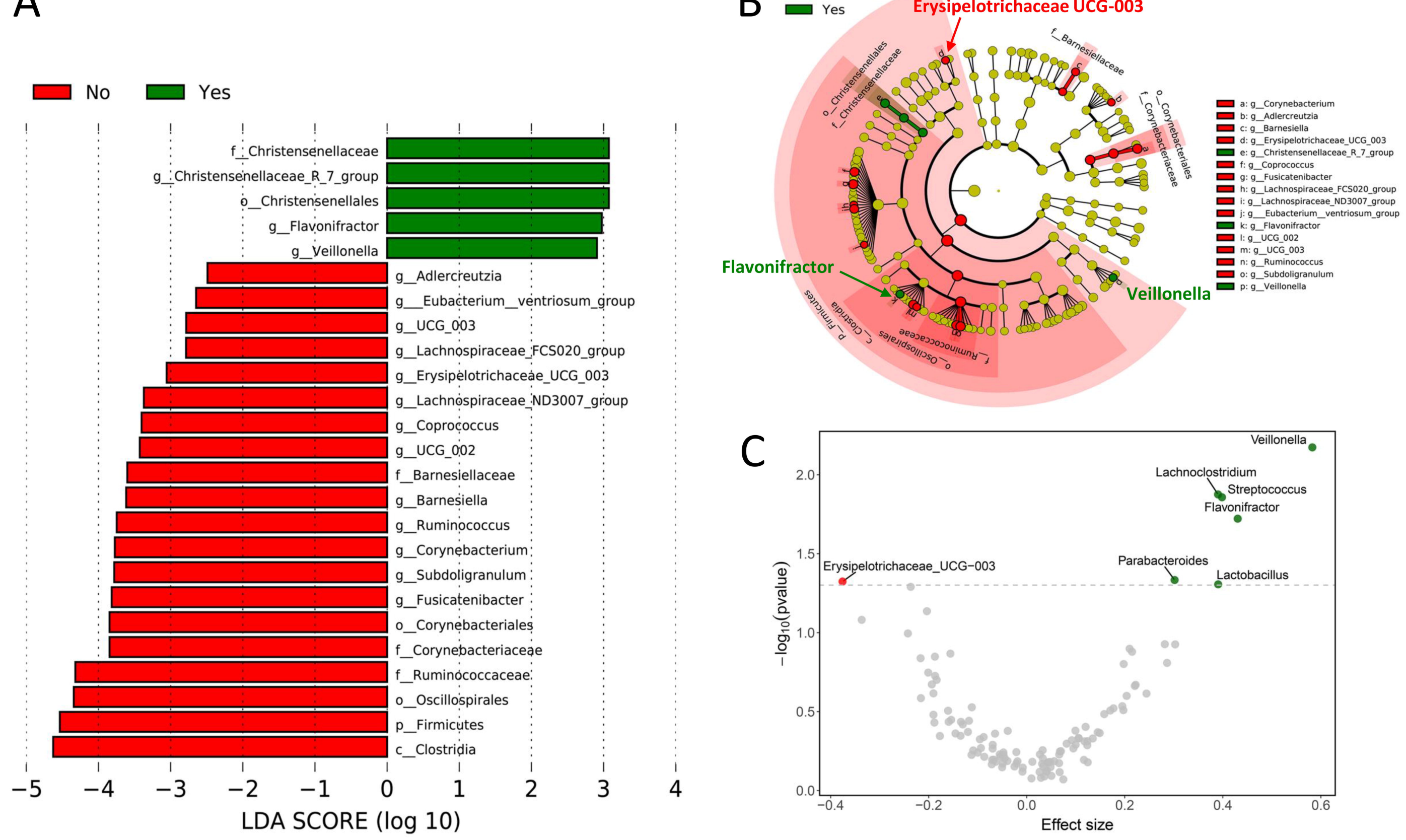

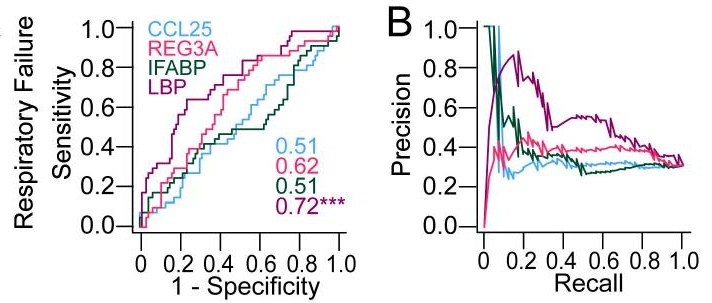

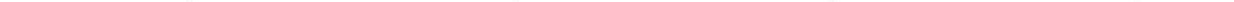